\title{
KERAGAAN CIRI KUANTITATIF MORFOLOGI GALUR-GALUR HARAPAN KEDELAI (Glycine max L. Merill) TAHAN CpMMV (Cowpea Mild Mottle Virus)
}

\author{
Tri Andri Setiawan ${ }^{1}$ \\ Siti Zubaidah ${ }^{2}$ \\ Heru Kuswantoro ${ }^{3}$ \\ ${ }^{1}$ Magister Pendidikan Biologi, Universitas Negeri Malang \\ ${ }^{2}$ Jurusan Biologi FMIPA Universitas Negeri Malang \\ ${ }^{3}$ Balai Penelitian Aneka Tanaman Kacang dan Umbi Malang \\ Email: biologyandri@yahoo.com
}

\begin{abstract}
Morphology is performance of a genotype that is influenced by environmental and genetic interaction. This research was to study the quantitatively morphological characters of ten CpMMV-resistant soybean promising lines, i.e. UM.4-1, UM.7-2, UM.2-4, UM.7-6, UM.6-2, UM.6-3, UM.3-2, UM.6-1, UM.7-3, UM.3-4 and two superior varieties Gumitir and Wilis. The study was conducted at Indonesian Legume and Tuber Crops Research Institute (ILETRI) from March to June 2015. The observation was done by measuring the quantitative morphological characters such as leaf length, leaf width, leaf petiol length, leaf area, leaf ratio $(P / L)$ and plant height. The data were tested using multivariate analysis. The results of the analysis showed that there were differences on morphological characters of CpMMV-resistant soybean promising lines as well as superior varieties Gumitir and Wilis based on the leaf length, leaf width, leaf petiol length, leaf area, leaf ratio $(P / L)$ and plant height. Hotelling's Trace (0.00) was smaller than the significance value (0.05) showing the differences among the groups.
\end{abstract}

Kata Kunci: kedelai, CpMMV, karakter morfologi kuantitatif

Indonesia merupakan negara agraris yang kaya akan pengelolaan pertanian, namun pada kenyataannya Indonesia merupakan negara yang masuk ke dalam isu krisis pangan dunia. Hal tersebut terjadi karena maraknya impor komoditas pangan yang dilakukan untuk memenuhi kebutuhan. Tahun 2010 Indonesia mengimpor komoditas pangan seperti garam $50 \%$, kedelai $70 \%$, jagung $11,23 \%$, kacang tanah $15 \%$ dan daging 23\% (INDEF, 2011). Berdasarkan data tersebut dapat dilihat bahwa Indonesia masih melakukan import terbesar pada komoditas kedelai yang mencapai $70 \%$ dari yang dibutuhkan. Data lain menunjukkan bahwa pada tahun 20102014 laju pertumbuhan ekspor kedelai di Indonesia rata-rata $7,4 \%$ per tahunnya, sedangkan impor kedelai mencapai $13,1 \%$ per tahun sehingga keadaan kedelai di Indonesia selalu berada dalam kondisi defisit jika dilihat dari kegiatan ekspor yang lebih rendah dibandingkan dengan impor yang dilakukan (Kementerian Pertanian Republik Indonesia, 2015).

Permasalah tersebut terjadi juga dipengaruhi oleh rendahnya produksi kedelai di Indonesia. Produksi kedelai menurun karena adanya faktor yang mempengaruhi salah satunya penyakit yang menyerang tanaman kedelai. Cowpea Mild Mottle Virus (CpMMV) merupakan contoh virus yang menyerang tanaman kedelai melalui hama kutu kebul (Bemisia tabaci) (Muniyapa, 1983). CpMMV merupakan virus yang secara alami juga berada pada inang tanaman Canavalia ensiformis (koro pedang), 
Arachis hypogaea (kacang tanah), Phaseolus lunatus (kacang kratok), $P$. vulgaris (buncis), Psophocarpus tetragonolobus (kecipir), Glycine max (kedelai), Lycopersicon esculentum (tomat), Vigna mungo (lentil hitam), Solanum melongena (terong), serta jenis kacang-kacangan lainnya (Smith, 2004).

CpMMV menginfeksi tanaman kedelai kemudian memanfaatkan kinerja seluler tanaman sehingga dapat menggangu kerja fisiologis tanaman kedelai yang dapat mengurangi kemampuan produktivitasnya (Ariyanti, 2013). Selain mengganggu kemampuan produktivitas kedelai, CpMMV juga dapat mempengaruhi morfologi tanaman kedelai. Berdasarkan penelitian mengenai perbandingan morfologi tanaman kedelai tahan CpMMV, muncul perbedaan pada karakter morfologi seperti panjang daun, panjang petiol daun, nisbah daun dan lebar daun (Arifin, 2012). Kedelai yang terinfeksi CpMMV dapat dilihat dengan indikator nekrotik lokal yang diikuti oleh mosaik sistemik, bintik ringan, dan nekrosis pada daun yang diikuti oleh keritingnya bagian bawah daun kedelai (Tavasoli dkk, 2009; Muniyappa, 1983).

Upaya yang dilakukan dalam mengurangi serangan penyakit CpMMV sudah dilakukan melalui pembentukan varietas baru secara konvensional. Proses perbaikan genetik tersebut merupakan salah satu bagian dari strategi pemuliaan tanaman. Varietas dibentuk melalui proses persilangan yang diharapkan dapat memperbaiki genetik tanaman kedelai yang tahan terhadap serangan penyakit CpMMV serta berdaya hasil tinggi (Zubaidah, dkk., 2010). Penelitian lain mengenai persilangan tanaman kedelai juga telah banyak dilakukan dengan tujuan untuk mengetahui keragaman kedelai (Dayaman, 2007), keragaman genetik plasma nutfah (Sulistyo, 2013) dan panduan peningkatan mutu benih secara genetik (Krisnawati dan Adie, 2008). Penelitian ini bertujuan untuk mengetahui keragaan ciri kuantitatif karakter morfologi galur-galur harapan tahan CpMMV serta varietas unggul Gumitir dan Wilis.

\section{METODE}

Penelitian ini menggunakan pendekatan secara kuantitatif. Penelitian dilakukan di Balai Penelitian Tanaman Aneka Kacang dan Umbi (BALITKABI) yang dilaksanakan pada bulan Maret-Juni 2015. Biji kedelai yang digunakan yaitu 10 galur kedelai (UM.4-1, UM.7-2, UM.2-4, UM.7-6, UM.6-2, UM.6-3, UM.3-2, UM.6-1, UM.7-3, UM.3-4) dan 2 varietas unggul sebagai pembanding (Gumitir dan Wilis). Ciri kuantitatif karakter morfologi yang diamati yaitu panjang daun, lebar daun, panjang petiol daun, luas daun, nisbah daun (P/L) dan tinggi tanaman. Luas permukaan daun dapat diukur dengan rumus yang telah diadaptasi sebagai berikut:

$\mathrm{L} 1=\frac{\mathrm{L} 2 \mathrm{xM} 1}{\mathrm{M} 2}$

(Gunarno, 2014)

Dimana: $\quad$ L1 $=$ Luas kertas berbentuk daun $\left(\mathrm{cm}^{2}\right)$

$\mathrm{M} 1=$ Massa kertas berbentuk daun (gr)

L2 = Luas kertas berukuran

$10 \mathrm{~cm} \times 10 \mathrm{~cm}\left(\mathrm{~cm}^{2}\right)$

M2 = Massa kertas

berukuran $10 \mathrm{~cm}$ x $10 \mathrm{~cm}$ (gr) 


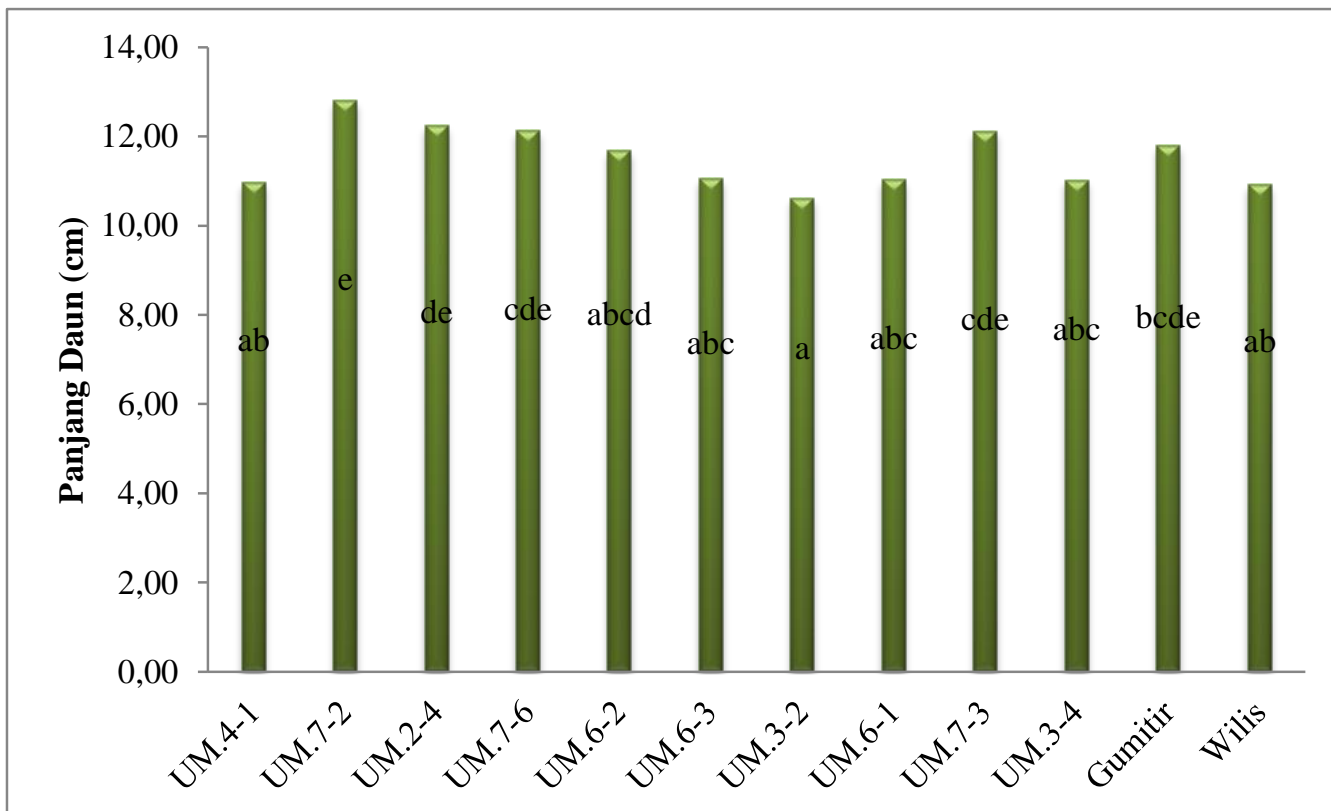

Gambar 1. Diagram Rata-rata Panjang Daun Kedelai

Keterangan: Perbedaan notasi huruf (a, b, c, d, e) pada diagram menunjukkan nilai berbeda nyata

\section{HASIL}

Data kuantitatif merupakan data morfologi tanaman yang meliputi panjang daun, lebar daun, panjang petiol daun, luas daun, nisbah daun $(\mathrm{P} / \mathrm{L})$ dan tinggi tanaman. Hasil identifikasi terhadap karakter morfologi secara kuantitatif dari 10 galur harapan tahan CpMMV dan 2 varietas unggul kedelai Gumitir dan Wilis memiliki perbedaan.

Hasil pengukuran panjang daun dari setiap galur dan varietas menunjukkan panjang yang bervariasi. Galur UM.7-2 memiliki ukuran daun paling panjang dibandingkan dengan galur lainnya termasuk Gumitir dan Wilis. Rata-rata pengukuran panjang daun diperoleh data seperti pada Gambar 1.

Lebar daun kedelai memiliki perbedaan ukuran yang sangat bervariasi disetiap sampel tanaman pada setiap galur dan varietas. Daun pada tanaman kedelai memiliki ukuran paling lebar terlihat pada galur UM.7-3 dibandingkan dengan galur-galur lainnya serta Gumitir dan Wilis. Setiap galur dan varietas memiliki ukuran lebar yang dapat dilihat pada Gambar 2. 


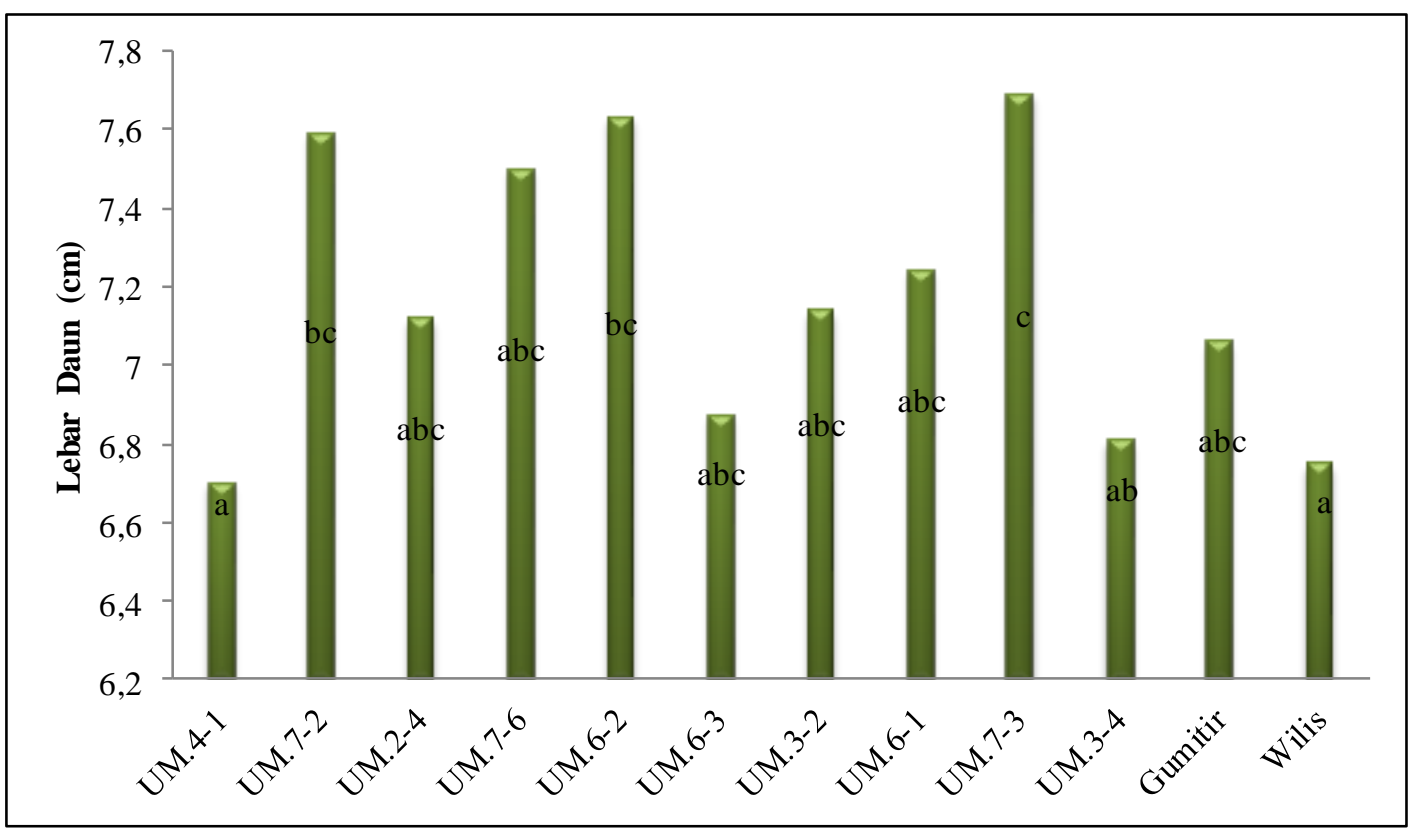

Gambar 2. Diagram Rata-rata Lebar Daun Kedelai

Keterangan: Perbedaan notasi huruf $(a, b, c)$ pada diagram menunjukkan nilai berbeda nyata

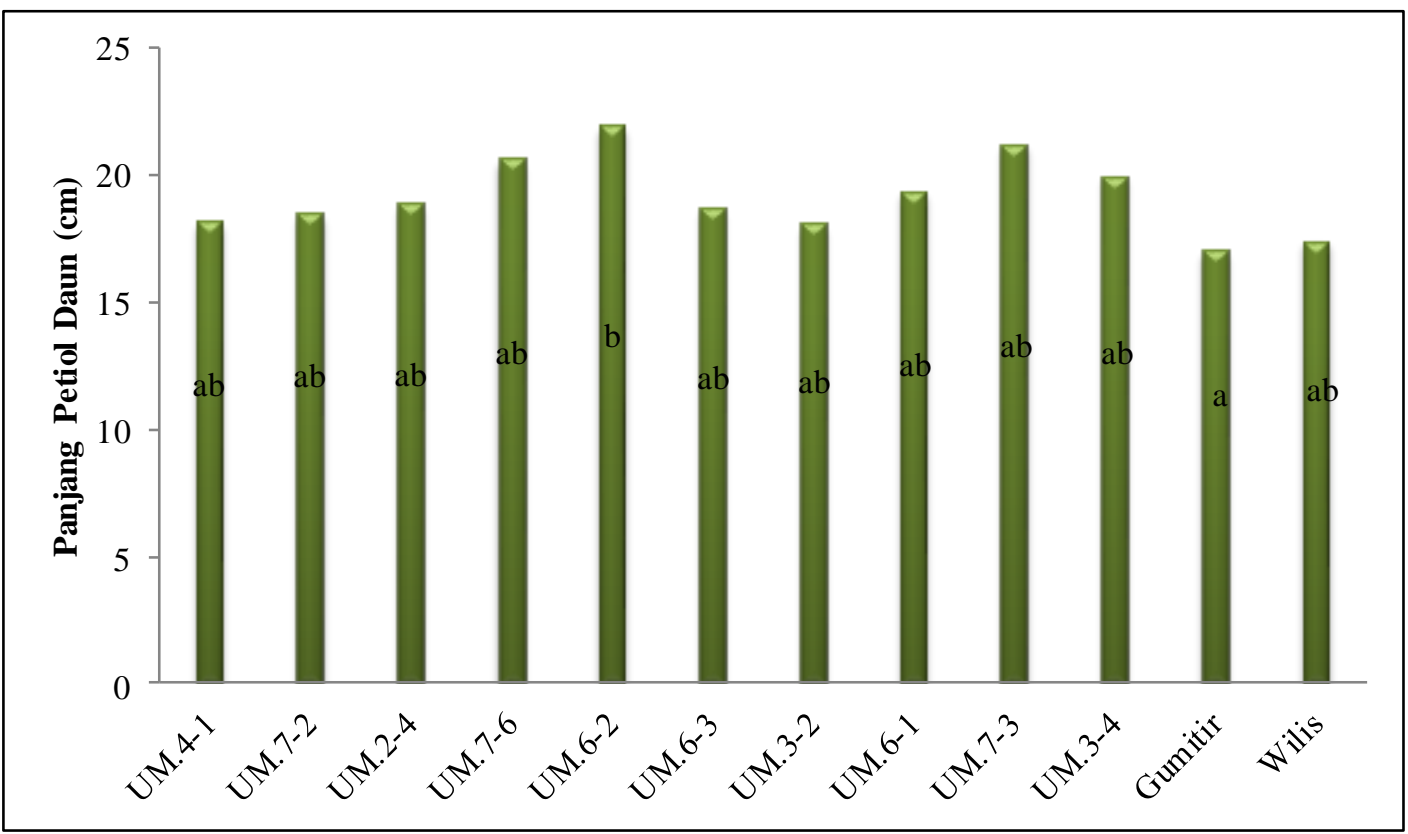

Gambar 3. Diagram Rata-rata Panjang Petiol Daun Kedelai Keterangan: Perbedaan notasi huruf ( $a$ dan $b$ ) pada diagram menunjukkan nilai berbeda nyata 


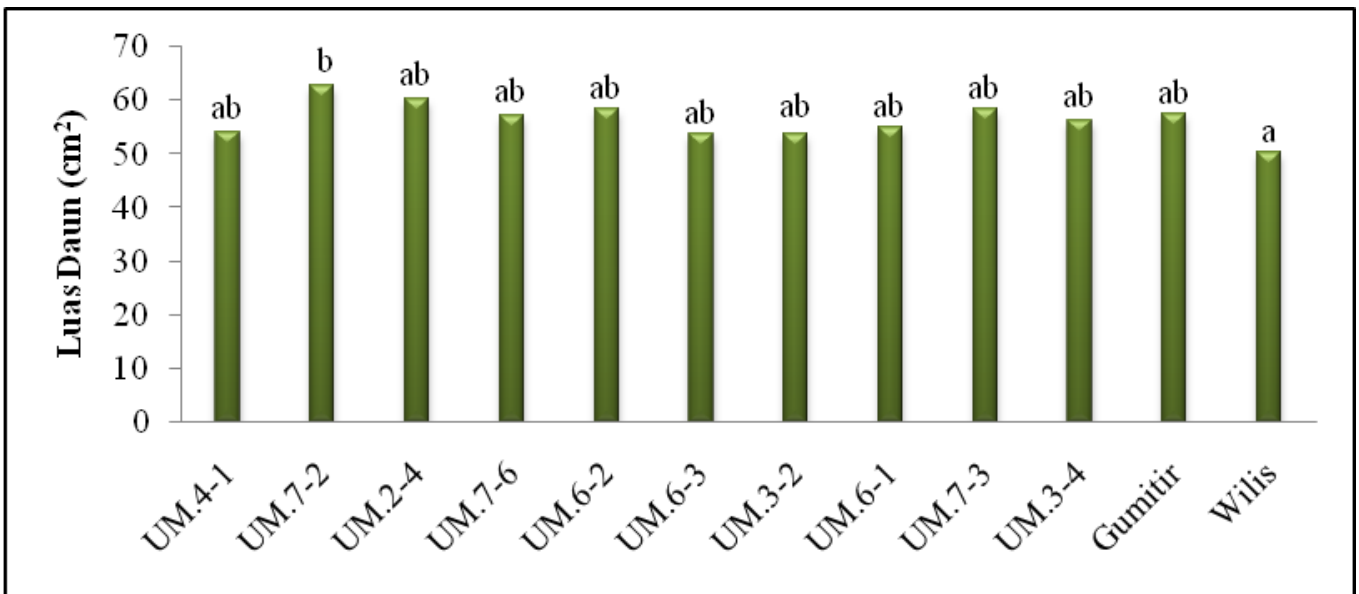

Gambar 4. Diagram Rata-rata Luas Daun Kedelai

Keterangan: Perbedaan notasi huruf ( $a$ dan $b$ ) pada diagram menunjukkan nilai berbeda nyata

Panjang petiol daun (tangkai daun) pada galur dan varietas memiliki ukuran yang sangat bervariasi. Hasil menunjukkan bahwa galur UM.6-2 memiliki petiol daun paling panjang dibandingkan galur lain serta Gumitir dan Wilis (Gambar 3).
Gambar 4 dapat dilihat bahwa luas daun kedelai setiap galur dan varietas memiliki luas berbeda. Terlihat bahwa galur UM.7-2 memiliki luas daun paling besar dibandingkan dengan galur-galur dan varietas lain. 


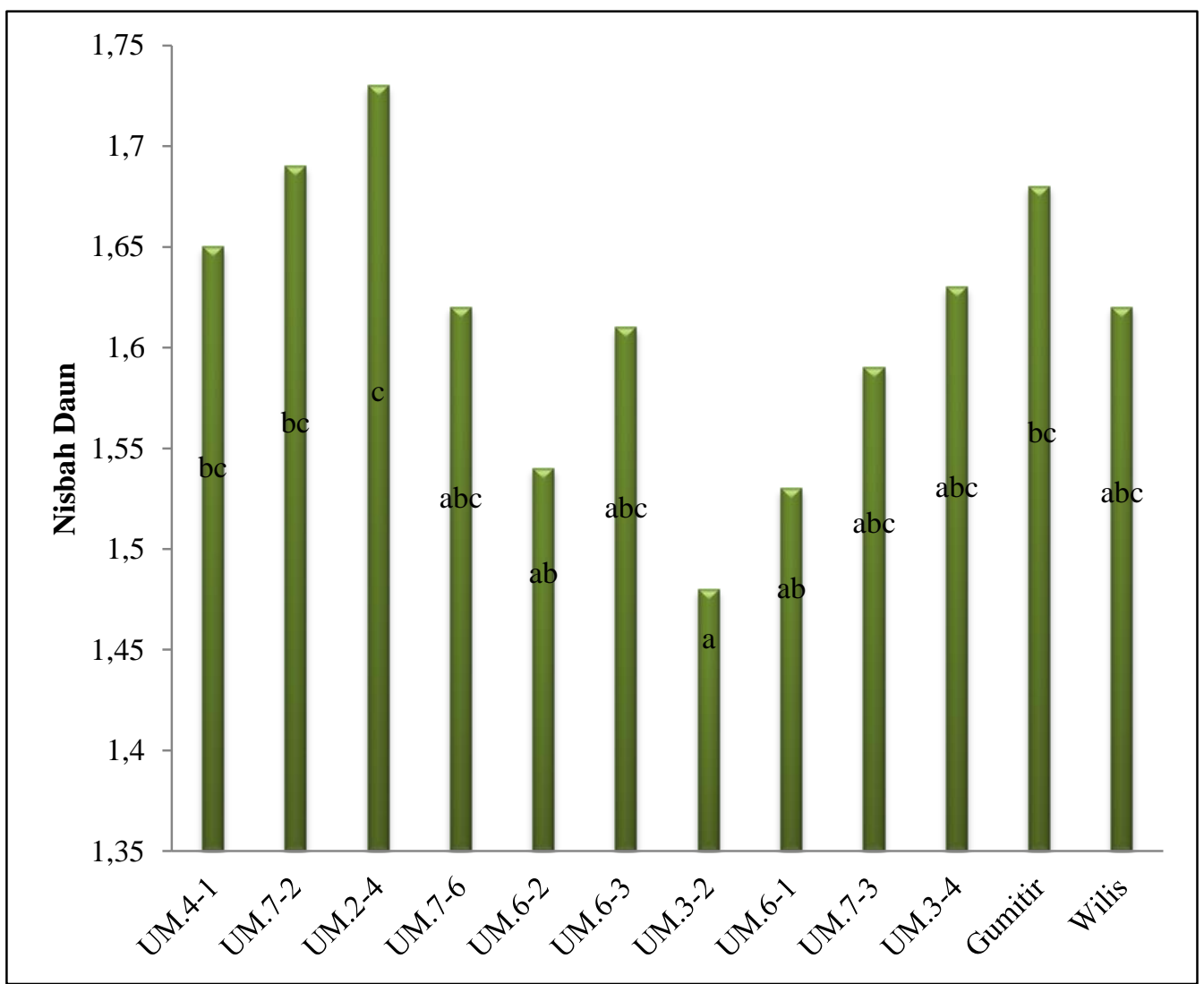

Gambar 5. Diagram Rata-rata Nisbah Daun (P/L) Kedelai

Keterangan: Perbedaan notasi huruf $(a, b, c)$ pada diagram menunjukkan nilai berbeda nyata



Gambar 6. Diagram Rata-rata Tinggi Tanaman Kedelai

Keterangan: Perbedaan notasi huruf $(\mathrm{a}, \mathrm{b}, \mathrm{c}, \mathrm{d})$ pada diagram menunjukkan nilai berbeda nyata 
Nisbah daun dihitung dengan membagi antara panjang $(\mathrm{P})$ dan lebar (L) daun kedelai yang telah diukur. Nisbah daun memiliki kecenderungan terhadap pertumbuhan bidang daun yang dapat dipengaruhi oleh faktor fisiologi tanaman kedelai. Nisbah daun setiap galur dan varietas memiliki hasil yang berbeda sesuai ukuran panjang dan lebar daunnya (Gambar 5). Hasil tersebut menunjukkan bahwa galur UM.2-4 memiliki nisbah daun (P/L) paling besar dibandingkan galur lain serta Gumitir dan Wilis.

Hasil pengukuran tinggi tanaman pada galur-galur harapan dan varietas unggul Gumitir dan Wilis menunjukkan adanya perbedaan tinggi tanaman antara setiap tanaman kedelai (Gambar 6). Hasil pengukuran tersebut menunjukkan bahwa 10 galur tahan CpMMV dan varietas unggul (Gumitir dan Wilis) pada penelitian ini memiliki rata-rata tinggi tanaman antara 57-83 cm. Galur UM.7-6 memiliki tanaman paling tinggi dibandingkan dengan galur lain dan varietas pembandingnya.

\section{PEMBAHASAN}

Sepuluh galur harapan UM.4-1, UM.7-2, UM.2-4, UM.7-6, UM.6-2, UM.6-3, UM.3-2, UM.6-1, UM.7-3, UM.3-4 serta dua varietas pembanding Gumitir dan Wilis memiliki keragaan ciri kuantitatif karakter morfologi yang berbeda. UM.7-2 memiliki daun lebih panjang sebesar $12,80 \mathrm{~cm}$. UM.7-3 memiliki daun lebih lebar sebesar 7,69 cm. UM.6-2 memiliki petiol daun lebih panjang sebesar 21,96 cm. UM.7-2 memiliki luas daun lebih besar yaitu $62,72 \mathrm{~cm}^{2}$. UM.2-4 memiliki nisbah daun lebih besar yaitu 1,73. UM.7-6 memiliki tinggi tanaman sebesar 82,59 $\mathrm{cm}$, lebih tinggi dibandingkan dengan galur dan varietas lain.

Perbedaan tersebut terjadi karena adanya perubahan karakter morfologi tanaman yang dapat dipengaruhi oleh adanya perubahan genetik melalui persilangan, mutasi, dan lingkungan hidup kedelai (Dayaman, 2007). Galur-galur harapan UM.4-1, UM.7-2, UM.2-4, UM.7-6, UM.6-2, UM.6-3, UM.3-2, UM.6-1, UM.7-3, UM.3-4 merupakan hasil persilangan kedelai tahan CpMMV dengan kedelai varietas unggul yang bertujuan memperbaiki genetik tanaman kedelai sehingga dapat menghasilkan keturunan kedelai yang tahan terhadap CpMMV dengan potensi hasil tinggi (Zubaidah dkk, 2010).

CpMMV juga dapat mempengaruhi pertumbuhan tanaman. Melalui plasmodesmata virus akan masuk ke dalam tanaman dan bereplikasi seiring dengan pembelahan sel. Coat protein $(\mathrm{CP})$ dan movement protein (MP) menyebabkan perpindahan virus antar sel yang berpindah secara bersamaan dengan virion hasil replikasi sel. Melalui retikulum endoplasma $\mathrm{CP}$ dan MP akan bergerak ke Viral Assembly Site (VAS) yang kemudian masuk ke dalam floem. Di dalam floem virus akan terus menyebar seiring dengan terjadinya proses translokasi pada tanaman (Ariyanti, 2013).

Pengaruh yang dapat terjadi dari infeksi virus yaitu dapat mengganggu perkembangan sel sehingga pertumbuhan sebagian organ tanaman tidak berjalan dengan baik. Hasil penelitian tanaman kedelai sehat tahan CpMMV menunjukkan bahwa pertumbuhan panjang daun, lebar daun, panjang petiol daun dan luas daun memiliki peningkatan dibandingkan dengan kedelai sakit. Hasil penelitian tersebut menunjukkan bahwa kedelai sehat memiliki panjang daun $6 \mathrm{~cm}$, lebar daun $5 \mathrm{~cm}$, panjang petiol daun 8 $\mathrm{cm}$ dan luas daun $29 \mathrm{~cm}^{2}$ (Arifin, 
2012). Jika dibandingkan dengan hasil penelitian tersebut, hasil pengukuran galur-galur harapan UM.4-1, UM.7-2, UM.2-4, UM.7-6, UM.6-2, UM.6-3, UM.3-2, UM.6-1, UM.7-3, UM.3-4 mengalami pertumbuhan morfologi yang lebih besar.

Berbeda dengan nisbah daun, kedelai sehat akan memiliki nisbah lebih kecil dibandingkan dengan kedelai sakit (Arifin, 2012). Hal tersebut berbeda dengan hasil pengukuran sampel yang menunjukkan bahwa nilai nisbah daun yaitu diantara 1,53-1,73 yang berarti lebih besar dibandingkan hasil pengukuran kedelai sehat yaitu 1 (Arifin, 2012). Nisbah daun merupakan hasil dari pembagian antara panjang $(\mathrm{P})$ dan lebar daun (L) sehingga hasil nisbah daun tidak dapat dipastikan karena sangat dipengaruhi oleh besar atau kecilnya hasil pengukuran panjang dan lebar daun.

Berdasarkan hasil pengukuran tinggi tanaman, hasil pengamatan menunjukkan bahwa kedelai memiliki tinggi antara $57-83 \mathrm{~cm}$. Berdasarkan data Deskripsi Varietas Unggul Kedelai, varietas unggul Gumitir memiliki tinggi tanaman $65 \mathrm{~cm}$ sedangkan varietas unggul Wilis memiliki tinggi tanaman $\pm 50 \mathrm{~cm}$ (Suhartina, 2005). Hal tersebut menunjukkan bahwa pertumbuhan tinggi tanaman sangat cepat dari ukuran tinggi tanaman kedelai yang dimiliki oleh varietas unggul. Berdasarkan pengalaman lapangan, jika tanaman kedelai terlalu tinggi juga akan mempengaruhi ketegaran tanaman. Curah hujan dan kecepatan angin yang tinggi dapat mengakibatkan tanaman kedelai mudah patah sehingga tanaman akan rebah atau tumbang.

Hasil analisis data menunjukkan bahwa dari 10 galur harapan UM.4-1, UM.7-2, UM.2-4, UM.7-6, UM.6-2, UM.6-3, UM.3-2,
UM.6-1, UM.7-3, UM.3-4 tahan CpMMV serta varietas unggul Gumitir dan Wilis memilki perbedaan pada karakter morfologi panjang daun, lebar daun, panjang petiol daun, luas daun, nisbah daun (P/L) dan tinggi tanaman dengan nilai Hotelling's Trace $(0,00)$ lebih kecil dari nilai signifikansi $(0,05)$ sehingga ada perbedaan antar kelompok.

\section{KESIMPULAN}

Berdasarkan hasil analisis dapat disimpulkan bahwa keragaan ciri kuantitatif karakter morfologi galurgalur harapan tahan CpMMV serta varietas unggul Gumitir dan Wilis menunjukkan bahwa terdapat perbedaan berdasarkan panjang daun, lebar daun, panjang petiol daun, luas daun, nisbah daun $(\mathrm{P} / \mathrm{L})$ dan tinggi tanaman.

\section{DAFTAR PUSTAKA}

Arifin, A.S. 2012. Kajian Morfologi Anatomi dan Agronomi antara Kedelai Glycine max Sehat dengan Kedelai yang terserang Cowpea Mild Mottle Virus (CpMMV) Serta Pemanfaatannya sebagai Bahan Ajar Pengelolaan Hama Terpadu di Sekolah Menengah Kejuruan. Tesis tidak diterbitkan. Malang: Fakultas Matematika dan Ilmu Pengetahuan Alam, Pendidikan Biologi, Universitas Negeri Malang.

Ariyanti, N.A. 2013. Mekanisme Infeksi Virus Kuning Cabai (Pepper Yellow Leaf Curl Virus) dan Pengaruhnya terhadap Proses Fisiologi Tanaman Cabai. Seminar Nasional IX Biologi FKIP UNS. Solo: UNS. 
Dayaman, V. 2007. Diversity Analysis in Soybean (Glycine max (L.) Merrill) Using Morphological and Simple Sequence Repeat (SSR) Markers. Coimbatore: Department of Plant Molecular Biology and Biotechnology, Centre for Plant Molecular Biology.

Gunarno. 2014. Pengaruh Pencemaran Udara Terhadap Luas Daun dan Jumlah Stomata Daun Rhoeo discolor. Medan: Widyaiswara Muda BDK.

INDEF. 2011. Krisis pangan dan kegagalan negara (online) http://indef.or.id/images/xplod/ news/press_release_indef $\% 20 \mathrm{p}$ angan.pdf. diakses pada 18 Februari 2016.

Kementerian Pertanian Republik Indonesia. 2015. Rencana Strategis Kementerian Pertanian 2015-2019. Jakarta: Menteri Pertanian Republik Indonesia.

Krisnawati, A. dan M.M. Adie. 2008. Ragam Karakter Morfologi Kulit Biji Beberapa Genotipe Plasma Nutfah Kedelai. Buletin Plasma Nutfah Vol. 14 No. 1 Th. 2008. Malang: Balai Penelitian Tanaman Kacangkacangan dan Umbi-umbian.

Muniyappa, V. 1983. Transmission of Cowpea Mild Mottle Virus by Bemisia tabaci in a Nonpersistent Manner. Plant Disease 67:391-393.
Smith, I.M. 2004. Cowpea Mild Mottle 'carlavirus' (Online) (http://gd.eppo.int/downfile/515 _datasheet_CPMMV0.pdf) diakses pada Minggu, 18 Oktober 2015.

Suhartina, 2005. Deskripsi Varietas Unggul Kacang-kacangan dan Umbi-umbian. Malang: Balai Penelitian Tanaman Kacangkacangan dan Umbi-umbian.

Sulistyo, A. 2013. Keragaman Genetik Plasma Nutfah Kedelai Berdasarkan Karakter Morfologi. Prosiding Seminar Nasional Hasil Penelitian Pertanian. KendalpayakMalang: Balai Penelitian Tanaman Kacang-kacangan dan Umbi-umbian (BALITKABI).

Tavasoli, M., N. Shahraeen dan SH. Ghorbani. 2009. Serological and RT-PCR Detection of Cowpea Mild Mottle Carlavirus Infecting Soybean. Journal of General and Molecular Virology Vol.1 (1), hal. 007011.

Zubaidah S, Corebima AD, dan Kuswantoro H. 2010. Pembentukan Varietas Unggul Kedelai Tahan CpMMV (Cowpea Mild Mottle Virus) Umur <80 Hari Berdaya Hasil Tinggi (Potensi Hasil >2,5 T/HA) dan Kehilangan Hasil $<10 \%$. Ringkasan Eksekutif Hasil-hasil Penelitian Tahun 2010. Malang: Universitas Negeri Malang. 